\title{
Occupational contact dermatitis caused by opioids: a case series
}

Ursula Flury ${ }^{1,2}$, Jennifer L. $\underline{\text { Cahill }}^{2}$ J, Rosemary L. Nixon ${ }^{2}$

1. Luzerner Kantonsspital (LUKS), Luzern, Switzerland

2. Occupational Dermatology Research and Education Centre, Skin and Cancer Foundation Inc, Carlton, Victoria, Australia

Corresponding author:

Dr. med. Ursula Flury, Zentrum für Dermatologie und Allergologie, Spitalstrasse 6000 Luzern 16, Switzerland, Email: ursula.flury@luks.ch

Conflict of interest: None to declare.

Running head: Occupational allergic contact dermatitis to opioids

This is the author manuscript accepted for publication and has undergone full peer review but has not been through the copyediting, typesetting, pagination and proofreading process, which may lead to differences between this version and the Version of Record. Please cite this article as doi: 10.1111/cod.13305

This article is protected by copyright. All rights reserved. 


\section{Abstract:}

Background: Opioid-manufacturing facility workers are at risk of developing occupational contact dermatitis.

Objectives: To describe the causes of occupational allergic contact dermatitis to opioids in an opioidmanufacturing facility.

Materials and Methods: A retrospective review was performed of patients assessed the Occupational Dermatology Clinic in Melbourne, Australia from 2004 to 2017.

Results: Fifteen workers from an opioid-manufacturing facility were assessed in our clinic over a period of 14 years. Of these, 11 individuals were diagnosed with occupational allergic contact dermatitis to opioids, with 7 reacting to thebaine, 5 to morphine, 4 to norhydroxymorphinone, 2 to codeine and 2 to oripavine. Two people were suspected of having immediate hypersensitivity reaction to opioids, including one who had allergic contact dermatitis as well. Two patients were diagnosed with urticaria, aggravated at work. One patient was diagnosed with a non-occupational rash.

Conclusions: We report a case series of workers with allergic contact dermatitis to opioids in a manufacturing facility. With greater awareness, including implementation of an educational programme and improved skin protection, the number of cases declined over time. Interestingly, norhydroxymorphinone had not been reported as an allergen before. Further testing is required to establish optimal patch test concentrations of all opiates.

Keywords: opioids; occupational allergic contact dermatitis; contact allergy; urticaria, opioidmanufacturing facility; patch test, case report 


\section{Introduction}

For thousands of years, opioids have been used for the treatment of pain. While classically the term 'opiate' was used to mean a drug derived from opium, now the term 'opioids' is used to denote all substances, both natural and synthetic, which bind to opioid receptors $(1,2)$. They can be divided into four different classes according to their chemical structure: phenanthrenes, benzomorphans, phenylpiperidines and diphenylheptanes (Figure 1) (3).

Phenanthrenes are the prototypical opioids. They are all composed of three fused benzene rings and include natural alkaloids such as morphine, codeine and thebaine $(3,4)$, but also semi-synthetic derivatives such as heroin (diacetylmorphine) and hydromorphone (4) (see Table 1).

Opioids can cause true allergies and pseudoallergies. The latter is caused by activation of mast cell degranulation through direct stimulation and opioid receptor activation, thereby releasing histamine (5). This causes skin reactions, such as flushing, urticaria or pruritus. Not all opioids have the same capacity to release histamine (5).

Opioid-plant workers risk becoming sensitized by exposures during the processing procedures. Cutaneous sensitization to topical opioids was first described in 1882, according to Touraine's extensive review (6). Subsequently cases of occupational ACD have been reported in morphineindustry workers, doctors, nurses and pharmaceutical workers (6-11). In 2012, Wootton and colleagues were the first to describe occupational ACD caused by oxycodone in three pharmaceutical workers (12). Recently Dekeyser reported ACD to oripavine (tested $5 \%$ pet., ethanol and aq.) for the first time, in a 35-year-old male working in a drug-manufacturing plant, who was also allergic to thebaine. (13).

Australia is one of the global players concerning the production and processing of poppy straw but no cases of occupational ACD have been reported to date (14). We report a case series of workers from an opioid-manufacturing facility who were referred to our clinic for patch testing over a 14 year period.

\section{CASE SERIES}

Sixteen workers were referred from a single opioid manufacturing plant for patch testing from 2004 to 2017 to our Occupational Dermatology Clinic, Melbourne, Australia. Patch testing was performed with our baseline series, any additional relevant allergen series, and a selection of opioids supplied from the workplace. The patches were removed at day (D)2 and readings were performed at D2 and D4. Opioids were tested initially according to the concentrations and vehicles reported (11) and modified subsequently after discussions regarding the solubility of opioids in different vehicles with factory chemists. The series as shown in Table 2 was devised. The first patient who described immediate symptoms was prick-tested, as well as patch tested. However, opioids are direct mast cell degranulators and comparison with controls soon revealed that such testing was not informative.

[Hier eingeben]

This article is protected by copyright. All rights reserved. 
The patients' characteristics and patch test reactions are summarized in Online supplemental Table 3. Sixteen individuals with a mean age of 36 years were assessed, 14 were patch tested and 1 was diagnosed with a non-occupational skin problem (details not included). The majority $(n=15,80 \%)$ were male. Most reported facial dermatitis, indicative of airborne contact dermatitis, although the hands and arms were also often involved. Eleven individuals were diagnosed with occupational ACD to opioids, with 7 reacting to thebaine, 5 to morphine, 4 to norhydroxymorphinone (NHM), 2 to codeine and 2 to oripavine. Three patients had also positive patch tests to substances other than opioids. One reacted to nickel sulfate and propyl gallate, and another to nickel sulfate, thiuram mix (including 2 thiuram constituents) and fragrance mix I. The third person had a positive reaction to methylchloroisothiazolinone. None of these reactions were thought to be relevant to the presenting skin condition.

One person (No. 9) reported rhinitis and asthma-like symptoms, with no rash, and was diagnosed with an immediate hypersensitivity reaction to morphine derivatives. Patch testing was not performed and the patient was referred to an allergist, but no follow up information was provided. Another two patients $($ No.12, 14) were negative on patch testing and were subsequently diagnosed with urticaria, although both had a clear history of aggravation in the workplace and improvement off work.

\section{DISCUSSION}

We present 11 cases of occupational ACD to opioids from a manufacturing facility in Australia. Two cases were suspected of having immediate hypersensitivity reactions, including asthma and 2 had urticaria that was exacerbated by their work exposures. Four of these reported cases were diagnosed as occupational ACD to NHM. To our knowledge, norhydroxymorphinone has not been described as an allergen, although it is classified as a phenanthrene. The substance was first tested by us in 2004 and the concentration of $3 \%$ pet. was chosen after testing several dilutions, however we have no longer have information about the testing performed at that time.

Many of the early cases were assessed some years ago in 2004, when it became clear that workers were being exposed inappropriately to opioid substances, leading to sensitization. This had occurred especially when substances were scraped out of a centrifuge and transferred to a different container. A worksite visit was undertaken and subsequently an educational programme highlighting the dangers of any skin contact with opioids was implemented. Very few cases of ACD were reported subsequently, until cases 11 and 13 recently. We believe this to be the largest case series from an opioid manufacturing facility reported to date, although we recognize that such problems may often be dealt with in-house and thus under-reported.

The majority of our workers with ACD experienced facial involvement, some with a clear-cut clinical pattern of airborne exposure. This made avoidance of the allergen in the workplace difficult, and in a number of cases, workers had to leave their employment because of ongoing ACD. Many of the cases reported in the literature described cross-reactions between different opioids within the same class

[Hier eingeben]

This article is protected by copyright. All rights reserved. 
$(4,15,16)$. Our data shows that out of 11 patients with ACD, 6 reacted to at least 2 substances. This might be an indicative of cross-reactivity, or alternatively, multiple exposures.

Some older reports have mentioned that workers with occupational ACD have developed the same or even more extensive skin eruptions after oral medicament intake of opioids (9-11). None of our workers described reactions to systemic opioids, but were warned about this possibility. In the event that a sensitized person requires narcotic analgesia, it would be useful to organize further investigations to answer this question. Mucosal or respiratory complaints from opioids has already been reported by Hogen Esch et al. They analysed serum for specific immunoglobulin $E$ to heroin, but a type 1 allergy to heroin could not be demonstrated. They assume that complaints were due to the histamine-liberating effect of heroin, to atopic constitutions, a combination of these factors or other non-allergic factors (17). Two workers described aggravation of urticaria at work. This was thought most likely to result from systemic exposure to small amounts of opioids, which are direct mast cell degranulators. In at least one case, it was necessary for the worker to leave the workplace.

In conclusion, we report a case series of workers with ACD to opioids in a manufacturing facility. There is no doubt that morphine, thebaine, NHM, oripavine and codeine are skin sensitizers. However, information is lacking with regard to the optimal patch test concentrations and further research is necessary.

\section{References}

1. Royston D, Hemmings HC. Physiology and Pharmacology for Anesthesia: Foundations and Clinical Application: Expert Consult - Online and Print.. Elsevier. p. 253. Available from: http://www.clinicalkey.com/dura/browse/bookChapter/3-s2.0-C20090417124

2. Benyamin R, Trescot AM, Datta S, Buenaventura R, Adlaka R, Sehgal N, et al. Opioid complications and side effects. Pain Physician. 2008 Mar;11(2 Suppl):S105-120.

3. Trescot AM, Datta S, Lee M, Hansen H. Opioid pharmacology. Pain Physician. 2008 Mar;11(2 Suppl):S133-153.

4. Sasseville $D$, Blouin $M-M$, Beauchamp C. Occupational allergic contact dermatitis caused by morphine. Contact Dermatitis. 2011 Mar;64(3):166-8.

5. Zhang B, Li Q, Shi C, Zhang X. Drug-Induced Pseudoallergy: A Review of the Causes and Mechanisms. Pharmacology. 2018;101(1-2):104-10.

6. Touraine A. les dermatoses del l'opium. 1936;53:449-60.

7. Anaphlyxis and Sensitization. Edinburgh: W. Green and Son, LTD, 192, p182, cited by Jordon J W 1939. In. 
8. Palmer RB. Conctact dermatitis due to codeine. Arch Dermatol. 1942 Jul 1;46(1):82.

9. Jordon JW, Osborne ED. Contact dermatitis from opium derivates: with special reference to occupational aspects. J Am Med Assoc [Internet]. 1939 Nov 25 [cited 2016 Dec 16];113(22). Available from:

http://jama.jamanetwork.com/article.aspx?doi=10.1001/jama.1939.02800470031007

10. Dore SE, Prosser Thomas EW. Contact dermatitis in a morphine factory. J Allergy. 1945 May;16(3):35-6.

11. Waclawski ER, Aldridge R. Occupational dermatitis from thebaine and codeine. Contact Dermatitis. 1995 Jul;33(1):51.

12. Wootton $\mathrm{Cl}$, English JS. Occupational allergic contact dermatitis caused by oxycodone. Contact Dermatitis. 2012 Dec;67(6):383-4.

13. Dekeyser S, van Tomme M, Boone B, van Geel N, Lapeere H. Occupational allergic contact dermatitis caused by thebaine and oripavine: CONTACT DERMATITIS CAUSED BY THEBAINE AND ORIPAVINE. Contact Dermatitis. 2017 Feb;76(2):120-2.

14. comments_E.pdf [Internet]. [cited 2016 Dec 17]. Available from: https://www.incb.org/documents/Narcotic-Drugs/TechnicalPublications/2015/comments_E.pdf

15. Rodriguez F, Fernandez L, Garcia-Abujeta JL, Maquiera E, Llaca HF, Jerez J. Generalized dermatitis due to codeine. Contact Dermatitis. 1995 Feb;32(2):120.

16. Rodriguez A, Barranco R, Latasa M, de Urbina JJO, Estrada JL. Generalized dermatitis due to codeine. Cross-sensitization among opium alkaloids. Contact Dermatitis. 2005 Oct;53(4):240-240.

17. Hogen Esch AJ, van der Heide S, van den Brink W, van Ree JM, Bruynzeel DP, Coenraads PJ. Contact allergy and respiratory/mucosal complaints from heroin (diacetylmorphine). Contact Dermatitis. 2006 Jan;54(1):42-9. 


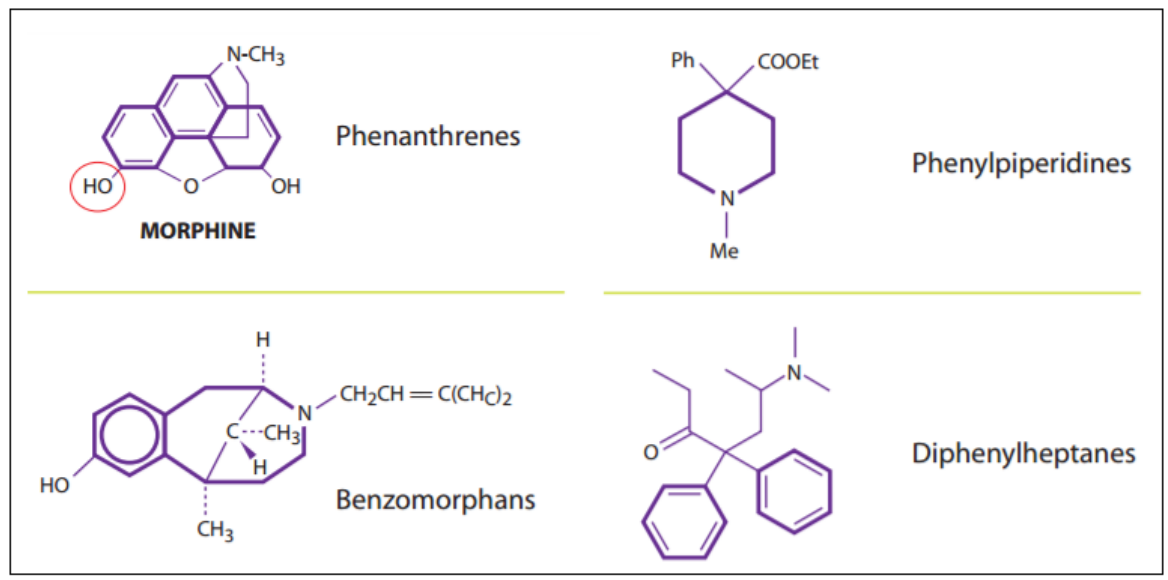

Figure 1. Chemical classification of opioids (3)

[Hier eingeben]

This article is protected by copyright. All rights reserved. 
Table 1. Four classes of opioids and their subtypes

\begin{tabular}{|c|c|c|c|}
\hline Phenanthrenes & Benzomorphans & Phenylpiperidines & Diphenylheptanes \\
\hline $\begin{array}{l}\text { - Morphine } \\
\text { - Codeine } \\
\text { - Hydromorphone } \\
\text { - Norhydroxy - } \\
\text { - morphinone } \\
\text { - Hydrocodone } \\
\text { - Oxymorphone } \\
\text { - Levorphanol } \\
\text { - Palbuphine } \\
\text { - Buprenorphine } \\
\text { - Oxycodone } \\
\text { - Heroin } \\
\text { - Oripavine } \\
\text { - Thebaine }\end{array}$ & - Pentazocine & $\begin{array}{ll}\text { - } & \text { Fentanyl } \\
\text { - } & \text { Alfentanil } \\
\text { - } & \text { Sufentanil } \\
\text { - } & \text { Meperidine } \\
& \text { (=Pethidine) }\end{array}$ & $\begin{array}{l}\text { - } \text { Propoxyphene } \\
\text { - Methadone }\end{array}$ \\
\hline
\end{tabular}


Table 2. Opioids used for testing

\begin{tabular}{|l|l|l|}
\hline Opioid & Conc. & Vehicle \\
\hline Morphine & $10 \%$ & $2 \%$ acetic acid \\
\hline Morphine & $5 \%$ & $2 \%$ acetic acid \\
\hline Morphine & $3 \%$ & $3 \%$ acetic acid \\
\hline Oripavine & $5 \%$ & $2 \%$ acetic acid \\
\hline Oripavine & $3 \%$ & $2 \%$ acetic acid \\
\hline Thebaine & $1 \%$ & ethanol \\
\hline Codeine CBA & $2.5 \%$ & ethanol \\
\hline Noscarpine & $0.5 \%$ & $2 \%$ acetic acid \\
\hline Noscarpine & $0.3 \%$ & $2 \%$ acetic acid \\
\hline Control & $2 \%$ and $3 \%$ acetic acid & aq. \\
\hline Norhydroxymorphinone (NHM) & $3 \%$ & pet. \\
\hline
\end{tabular}

[Hier eingeben]

This article is protected by copyright. All rights reserved. 


\section{University Library}

\section{- M M I E E R VA A gateway to Melbourne's research publications}

Minerva Access is the Institutional Repository of The University of Melbourne

Author/s:

Flury, U;Cahill, JL;Nixon, RL

Title:

Occupational contact dermatitis caused by opioids: A case series

Date:

2019-11-01

Citation:

Flury, U., Cahill, J. L. \& Nixon, R. L. (2019). Occupational contact dermatitis caused by opioids: A case series. CONTACT DERMATITIS, 81 (5), pp.332-335. https://doi.org/10.1111/ cod.13305.

Persistent Link:

http://hdl.handle.net/11343/285951 